\title{
The complete mitochondrial genome of the tapeworm Cladotaenia vulturi (Cestoda: Paruterinidae): gene arrangement and phylogenetic relationships with other cestodes
}

\author{
Aijiang Guo ${ }^{1,2}$
}

\begin{abstract}
Background: Tapeworms Cladotaenia spp. are among the most important wildlife pathogens in birds of prey. The genus Cladotaenia is placed in the family Paruterinidae based on morphological characteristics and hosts. However, limited molecular information is available for studying the phylogenetic position of this genus in relation to other cestodes.

Methods: In this study, the complete mitochondrial (mt) genome of Cladotaenia vulturi was amplified using "Long-PCR" and then sequenced by primer walking. Sequence annotation and gene identification were performed by comparison with published flatworm mt genomes. The phylogenetic relationships of $C$. vulturi with other cestode species were established using the concatenated amino acid sequences of 12 protein-coding genes with Bayesian Inference and Maximum Likelihood methods.

Results: The complete mitochondrial genome of the Cladotaenia vulturi is 13,411 kb in size and contains 36 genes. The gene arrangement of C. vulturi is identical to those in Anoplocephala spp. (Anoplocephalidae), Hymenolepis spp. (Hymenolepididae) and Dipylidium caninum (Dipylidiidae), but different from that in taeniids owing to the order shift between the tRNA (L1) and tRNA (S2) genes. Phylogenetic analyses based on the amino acid sequences of the concatenated 12 protein-coding genes showed that the species in the Taeniidae form a group and C. vulturi is a sister taxon to the species of the family Taeniidae.

Conclusions: To our knowledge, the present study provides the first molecular data to support the early proposal from morphological evidence that the Taeniidae is a sister group to the family Paruterinidae. This novel mt genome sequence will be useful for further investigations into the population genetics, phylogenetics and systematics of the family Paruterinidae and inferring phylogenetic relationships among several lineages within the order Cyclophyllidea.
\end{abstract}

Keywords: Mitochondrial genome, Cladotaenia vulturi, Comparative genomics, Phylogeny, Cestoda, Cyclophyllidea Abbreviations: Bl, Bayesian inference; ML, Maximum likelihood; Mt, Mitochondrial

\footnotetext{
Correspondence: guoaijiang@caas.cn

'State Key Laboratory of Veterinary Etiological Biology, Key Laboratory of Veterinary Parasitology of Gansu Province, Lanzhou Veterinary Research Institute, Chinese Academy of Agricultural Sciences, Lanzhou 730046, Gansu Province, People's Republic of China

${ }^{2}$ Jiangsu Co-Innovation Center for Prevention and Control of Important

Animal Infectious Diseases and Zoonoses, Yangzhou 225009, Jiangsu

Province, People's Republic of China
} 


\section{Background}

Tapeworms Cladotaenia spp. are among the most important wildlife pathogens of birds of prey. Historically, the genus Cladotaenia Cohn, 1901 was created within Taeniidae based on morphological similarities [1]. The uterus of Cladotaenia spp. consists of median stem and lateral branches, similar to the species in the family Taeniidae [1]. While the life-cycles of all species in the family Taeniidae involve two mammals, the definitive hosts of the genus Cladotaenia are birds of prey [1]. Thus, authorities have removed the genus Cladotaenia from the family Taeniidae to the Paruterinidae [1] based on morphological and biological grounds. In the current classification, the family Paruterinidae includes all of the cyclophyllidean cestodes with paruterine organs which cannot be related to other families having similar uterine structures [1]. Five genera (Paruterina, Cladotaenia, Culcitella, Laterotaenia and Matabelea) are considered as the Paruterinidae [1]. The systematics of the Paruterinidae have been problematic [2] and there are few studies investigating the phylogeny of the Paruterinidae including Cladotaenia [2, 3].

Molecular tools have been used to study phylogenetic relationships among groups of cyclophyllidean tapeworms [4-9]. However, the limited availability of sequence data has greatly impeded studies of the phylogenetic relationships among families in the order Cyclophyllidea. Compared to some genes $(18 S, 12 S$ and cox 1$)$, complete mtDNA sequences are more informative at the generic level $[8,10]$. Complete mitochondrial DNA sequences can provide not only individual and combined mt genes but also gene order. Mitochondrial gene rearrangement is generally a rare event occurring over long periods of evolutionary time [11], although mitochondrial sequences evolve rapidly in metazoans [12]. Relative gene rearrangement found in a group of species is considered evidence of having closer relationship [13]. Indeed, gene rearrangement comparisons used as phylogenetic tools have been well discussed $[14,15]$ and used to analyze several evolutionary relationships in echinoderms [16], arthropods [17, 18], gastropods [19] and annelids [20]. However, only 37 complete cestode mitochondrial genome sequences are available for species of the order Cyclophyllidea in the NCBI database and no complete mitochondrial genome was available in the family Paruterinidae until now.

The present study aimed to (i) characterize the complete mt genome of C. vulturi, the first representative of the family Paruterinidae; (ii) compare its mt gene content, arrangement with those of other cestodes; and (iii) infer the phylogenetic position of C. vulturi in relation to other tapeworms based on the concatenated $\mathrm{mt}$ amino acid sequences.

\section{Methods}

\section{Sample collection}

In 2013, an emaciated wild Aquila nipalensis (steppe eagle) was found in Kashi, Xinjiang, China, and then was taken to a Zoo where it died soon after. Six tapeworms were found in the intestine of this $\operatorname{dead} A$. nipalensis with scolices firmly attached to the intestinal wall. In order to obtain the whole tapeworms, intestinal segment with the attached scolices was excised and immersed in water for 5-6 h for separating and stretching the tapeworms. Each of the six tapeworms was morphologically identified by light microscopy and electron microscopy. Individual scolices were fixed in $2.5 \%$ gultaraldehyde. The structure of the scolex was observed by scanning electron microscope. Mature and gravid proglottides were placed in $70 \%$ ethanol solution and stained with hematoxylin and eosin staining kit (Beijing CellChip Biotechnology Co. Ltd, Beijing, China). Morphological observation included rostellum, hooks, suckers and testes and ovary [1]. All six tapeworms were identified as C. vulturi according to keys to the cestode parasites of vertebrates [1]. The tapeworm used for DNA extraction was kept in $70 \%$ ethanol solution and two tapeworms were fixed in $5 \%$ formalin solution; these were archived in the Parasitological Museum of Lanzhou Veterinary Research Institute, Lanzhou, Gansu, China, under collection number PML 1996.

\section{DNA extraction, amplification and sequencing}

Total genomic DNA was extracted from a single adult using the Tissue DNA kit (OMEGA, Doraville, USA) according to the manufacturer's protocol. First, the partial gene fragments for nad1, nad5 and $r r n S$ were amplified using published primer sets designed according to the published conserved regions of the cestode species [21, 22] (Additional file 1: Table S1). PCR reactions for these three partial fragments were performed in a $50 \mu \mathrm{l}$ reaction volume consisting $25 \mu \mathrm{l}$ of LA Taq Premix buffer (TaKaRa Biotechnology Co, Dalian, China), $22.5 \mu \mathrm{l}$ of sterile deionized water, $0.5 \mu \mathrm{l}$ of each primer $(50 \mathrm{pmol} /$ $\mu \mathrm{l})$, and $1.5 \mu \mathrm{l}$ of DNA template $(40 \mathrm{ng} / \mu \mathrm{l})$ with the following conditions: $94{ }^{\circ} \mathrm{C}$ for $5 \mathrm{~min}$, then $94{ }^{\circ} \mathrm{C}$ for $10 \mathrm{~s}, 55{ }^{\circ} \mathrm{C}$ for $30 \mathrm{~s}, 72{ }^{\circ} \mathrm{C}$ for $1 \mathrm{~min}$ for 30 cycles, followed by $72{ }^{\circ} \mathrm{C}$ for $7 \mathrm{~min}$. Then the three overlapping long PCR fragments were amplified using Long-PCR primer sets, designed according to the above mentioned three primer sets (Additional file 1: Table S1). PCR reactions were conducted in $50 \mu \mathrm{l}$ mixture including $25 \mu \mathrm{l}$ of LA Taq Premix buffer (TaKaRa Biotechnology Co, Dalian, China), $22.5 \mu \mathrm{l}$ of sterile deionized water, $0.5 \mu \mathrm{l}$ of each primer $(50 \mathrm{pmol} / \mu \mathrm{l})$, and $1.5 \mu \mathrm{l}$ of DNA template (40 $\mathrm{ng} / \mu \mathrm{l})$. The amplification conditions of the three long-PCR reactions consisted of $94{ }^{\circ} \mathrm{C}$ for $5 \mathrm{~min}$, then $94{ }^{\circ} \mathrm{C}$ for $10 \mathrm{~s}, 50{ }^{\circ} \mathrm{C}$ for $30 \mathrm{~s}, 68{ }^{\circ} \mathrm{C}$ for $10 \mathrm{~min}$ for 
30 cycles, followed by $68{ }^{\circ} \mathrm{C}$ for $10 \mathrm{~min}$. PCR products of the nad1, nad5 and rrnS gene fragments were purified, cloned and sequenced. PCR products of the three Long-PCR fragments were sequenced in both directions using the 'primer walking' method after gel purification. The complete mtDNA sequence was assembled using Sequencher ver. 3.1.1 (GeneCodes) by overlapping regions between the long PCR fragments and three partial sequences.

\section{Sequence annotation and gene identification}

MacVector 8.1.2 was used to annotate the sequence through comparison with published flatworm genomes. The reading frames were translated using flatworm $\mathrm{mt}$ code (translation table 9). Twelve mt protein-coding genes were determined by similarity comparisons of inferred amino acid sequences to those of other flatworm mtDNAs. Two ribosomal RNA genes were identified by finding gene boundaries based on comparison with other flatworm mtDNA sequences. The 22 tRNA genes were searched by using the tRNAscan-SE software and by eye detecting potential secondary structures and anticodon sequences. Secondary structures in the two larger non-coding regions were predicted with the Mfold program [23].

\section{Phylogenetic analysis}

A total of $45 \mathrm{mt}$ genome sequences were used in the phylogenetic analysis, including all of the mitochondrial genomes of cyclophylidean tapeworms available on GenBank [10], the mt genome for C. vulturi identified in this study, six mt genomes of species of the Pseudophyllidea, and the mt genome of Schistosoma japonicum (Trematoda) as the outgroup. Phylogenetic analyses were performed using the concatenated amino acid sequences of 12 protein-coding genes. The amino acid sequences for each protein-coding gene of the 45 species were aligned individually using MAFFT 7.122 [24]. Poorly aligned positions were discarded by Gblocks [25], using the option for a less stringent selection. A single alignment for phylogenetic analyses was conducted by concatenating all amino acid alignments of the 12 protein-coding genes. The optimal model for phylogenetic analysis was selected by ProtTest [26]. The phylogenetic trees were constructed using Maximum Likelihood (ML) and Bayesian Inference (BI) analyses. ML analysis was conducted by PhyML 3.0 software [27] with MtArt $+\mathrm{I}+\mathrm{G}$ model, and 100 bootstrap replicates were chosen to calculate bootstrap support for ML trees. BI analysis was performed using MrBayes 3.2 software [28] with mtZoa model (rates = gamma, ngammacat $=5$ ), as suggested by Rota-Stabelli et al. [29]. Two chains were run for 5,000,000 generations and sampled every 1,000 generations. The first $25 \%$ of the trees were treated as 'burn-in' and Bayesian posterior probabilities were calculated for the remaining trees.

\section{Relative synonymous codon usage}

To examine the codon usage variation among the 12 protein-coding $\mathrm{mt}$ gene sequences of cestode species, relative synonymous codon usage values (RSCU) of different codons [30] in each representative cestode species were calculated using CodonW (Version 1.4.2). Then a dendrogram was produced by the hierarchical clustering algorithm implemented in Gene Cluster (V3.0) based on the RSCU values.

\section{Results and discussion}

\section{Amplification of the mtDNA of Cladotaenia vulturi}

The three long fragments with three overlapping fragments of nad1, nad5 and $r r n S$ jointly represent the complete $\mathrm{mt}$ genome of $C$. vulturi. The assembled sequence shows that the $\mathrm{mt}$ genome of C. vulturi (GenBank accession No. KU559932) is circular, 13,411 bp long (Fig. 1), making it the smallest among the mt genomes of cestode species reported to date (range 13,482-14,459 bp). The nucleotide composition of AT in mtDNA of C. vulturi is $74.64 \%$, which is slightly higher than that reported for other cestode species to date.

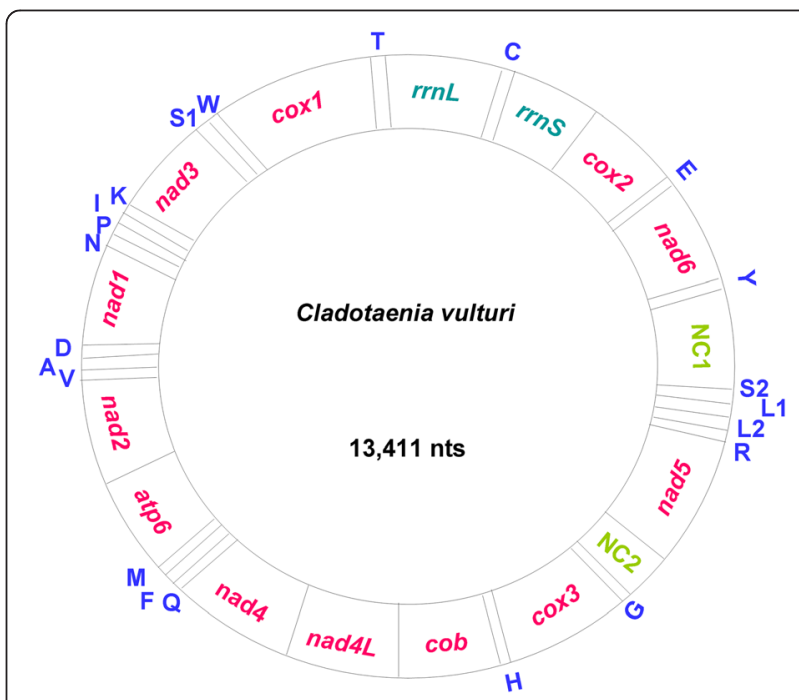

Fig. 1 The mitochondrial genome of Cladotaenia vulturi. Genome organization of the complete mitochondrial genome of Cladotaenia vulturi is a circular DNA molecule containing 36 genes. All genes are coded by the same DNA strand and are transcribed in the same direction. Protein-coding and rRNA genes are shown with the standard nomenclature. tRNA genes are designated with the one letter code of their corresponding amino acids, where $L_{1}$ and $L_{2}$ represent individual leucine codons CUN and UUR; and $S_{1}$ and $S_{2}$ represent serine codons AGN and UCN, respectively. "NC" refers to the non-coding region 


\section{Gene content and organization}

Thirty-six genes including 12 protein-coding genes (nad16, nad4L, cox1-3, cob and atp6), two ribosomal RNA genes ( $r r n S$ and $r r n L$ ), and 22 transfer RNA (trn) genes were identified in the mt genome of C. vulturi (Table 1). As with previously reported flatworm $\mathrm{mt}$ genomes, $C$. vulturi lacks the atp8 gene, which is found in animal mt DNAs. All of these genes were coded unidirectionally, on the plus strand (Fig. 1), a condition observed in other flatworms. The gene arrangement of $C$. vulturi, however, exhibited a slight difference from those of species in the family Taeniidae, with the reversal in the position of $\operatorname{trn} S$ (UCA) and $\operatorname{trnL}$ (CUA).

Table 1 Summary data for the annotated mitochondrial genome of Cladotaenia vulturi

\begin{tabular}{|c|c|c|c|c|c|}
\hline Gene & Position/ length & Initiation/ termination codon & Anticodon & No. of amino acids & No. of intergenic nucleotides ${ }^{a}$ \\
\hline $\operatorname{cox} 1$ & $1-1,584 / 1,584$ & GTG/TAG & - & 527 & +6 \\
\hline $\operatorname{trn} T$ & $1,575-1,635 / 61$ & - & TGT & - & -10 \\
\hline$r r n L$ & $1,636-2,599 / 964$ & - & - & - & 0 \\
\hline $\operatorname{trn} C$ & $2,600-2,662 / 63$ & - & GCA & - & 0 \\
\hline$r r n s$ & $2,663-3,377 / 715$ & - & - & - & 0 \\
\hline $\cos 2$ & $3,378-3,959 / 582$ & GTG/TAA & - & 193 & 0 \\
\hline $\operatorname{trn} E$ & $3,962-4,027 / 66$ & - & TTC & - & +2 \\
\hline nad6 & $4,030-4,485 / 456$ & ATG/TAG & - & 151 & +2 \\
\hline $\operatorname{trn} Y$ & $4,489-4,552 / 64$ & - & GTA & - & +3 \\
\hline Non-coding region ( $\mathrm{NC} 1$ ) & $4,553-4,687 / 135$ & - & - & - & 0 \\
\hline $\operatorname{trnS2}$ & $4,688-4,750 / 63$ & - & TGA & - & 0 \\
\hline $\operatorname{trnL1}$ & $4,759-4,823 / 65$ & - & TAG & - & +8 \\
\hline $\operatorname{trn} L 2$ & $4,832-4,894 / 63$ & - & TAA & - & +8 \\
\hline $\operatorname{trn} R$ & $4,902-4,958 / 57$ & - & ACG & - & +7 \\
\hline nad5 & $4,960-6,528 / 1569$ & ATG/TAA & - & 522 & +1 \\
\hline Non-coding region (NC2) & $6,529-6,636 / 108$ & - & - & - & 0 \\
\hline $\operatorname{trn} G$ & $6,637-6,705 / 69$ & - & TCC & - & 0 \\
\hline $\cos 3$ & $6,707-7,351 / 645$ & GTG/TAA & - & 214 & +1 \\
\hline $\operatorname{trnH}$ & $7,355-7,420 / 66$ & - & GTG & - & +3 \\
\hline cytb & $7,424-8,517 / 1094$ & ATG/TA & - & 364 & +3 \\
\hline nad4L & $8,518-8,778 / 261$ & ATG/TAA & - & 86 & 0 \\
\hline nad4 & $8,739-9,983 / 1245$ & GTG/TAA & - & 414 & -40 \\
\hline $\operatorname{trn} Q$ & $9,984-10,046 / 63$ & - & TTG & - & 0 \\
\hline $\operatorname{trnF}$ & $10,047-10,108 / 62$ & - & GAA & - & 0 \\
\hline $\operatorname{trnM}$ & $10,105-10,167 / 63$ & - & CAT & - & -4 \\
\hline atp6 & $10,169-10,684 / 516$ & ATG/TAA & - & 171 & +1 \\
\hline nad2 & $10,689-11,564 / 876$ & ATG/TAA & - & 291 & +4 \\
\hline $\operatorname{trn} V$ & $11,574-11,637 / 64$ & - & TAC & - & +9 \\
\hline $\operatorname{trn} A$ & $11,643-11,707 / 65$ & - & TGC & - & +5 \\
\hline $\operatorname{trn} D$ & $11,711-11,776 / 66$ & - & GTC & - & +3 \\
\hline nadl & $11,779-12,669 / 891$ & ATG/TAA & - & 296 & +2 \\
\hline $\operatorname{trnN}$ & $12,673-12,734 / 62$ & - & & - & +3 \\
\hline $\operatorname{trn} P$ & $12,736-12,799 / 64$ & - & & - & +1 \\
\hline trnl & $12,800-12,862 / 63$ & - & & - & 0 \\
\hline $\operatorname{trnK}$ & $12,868-12,930 / 63$ & - & & - & +5 \\
\hline nad3 & $12,934-13,281 / 348$ & $\mathrm{GTG} / \mathrm{TAG}$ & - & 115 & +3 \\
\hline $\operatorname{trnS1}$ & $13,280-13,338 / 59$ & - & $\mathrm{GCT}$ & - & -2 \\
\hline $\operatorname{trn} W$ & $13,343-13,405 / 63$ & - & TCA & - & +4 \\
\hline
\end{tabular}

${ }^{a}$ Minus sign (-) and plus sign (+) show the length of overlap and intergenic gap between two adjacent genes respectively 


\section{Initiation and termination codons and protein-coding genes}

Initiation and termination codons inferred from each protein-coding gene are shown in Table 1 . The inferred start codon for seven of the 12 protein-coding genes in C. vulturi was ATG, while the inferred start codon for the other five protein-coding genes (cox1-3, nad3 and nad4) was GTG. For the nad4 gene, there was another eligible start codon (ATG) in-frame that is a reasonable alternative, and the sizes of the inferred amino terminal residues from the start codons GTG and ATG were 414 aa and 412 aa, respectively. Eleven of the 12 proteincoding genes in the mt genome of $C$. vulturi can be inferred to end with a complete stop codon (three are TAG and eight are TAA). Only one abbreviated stop codon (TA) was found, for the $c y t b$ gene; abbreviated stop codons ( $\mathrm{T}$ or $\mathrm{TA}$ ) have also been found in the $\mathrm{mt}$ protein-coding genes of other cestode species [31]. An alternative complete stop codon (TAG) for the $c y t b$ gene is possible in-frame that would share one nt $(G)$ with the downstream nad4L gene. The length for each of 12 proteins, deduced form each protein-coding gene, was similar to those already characterized for other cestodes (Table 2).

Overlap was found between nad4L and nad4, as is common among metazoan $\mathrm{mt}$ genomes for these two genes [12]. Overlap also appeared between $\operatorname{trnF}$ and trnM. Indeed, overlaps between tRNA genes are common among $\mathrm{mt}$ genomes [12]. It is noteworthy that overlaps were detected between the $\operatorname{cox} 1$ and $\operatorname{trn} T$ genes (10 bp overlap), and the nad3 and trnS1 (AGN) genes (2 bp overlap) in the mt genome of C. vulturi. However, the overlap between protein-coding and tRNA genes is uncommon. Among the tapeworms, an overlap between protein-coding and tRNA genes has been found only between the nad1 and trnD genes in Schistosoma haematobium [32].

\section{Ribosomal and transfer RNA genes}

The ribosomal RNA genes $r r n S$ and $r r n L$ of $C$. vulturi are $715 \mathrm{bp}$ and $964 \mathrm{bp}$ long, respectively (Table 1). rrnS is located between $\operatorname{trnC}$ and cox 2 and $r r n L$ is positioned between $r r n T$ and $r r n C$. The sizes and positions of $r r n S$ and $r r n L$ in $C$. vulturi are similar to those in other cestodes. Twenty-two transfer RNA genes (tRNA) were identified in $C$. vulturi with the length of the individual tRNA genes ranging between 57 and 69 bp (Table 1). Eighteen of the 22 tRNA nucleotide sequences have the potential to form a standard cloverleaf structure, the exceptions comprising trnS1 (AGN), trnS2 (UCN), trnC and $t r n R$, all lacking a DHU arm (Additional file 2: Figure S1). Inferred tRNA secondary structures for $C$. vulturi exhibited no differences when compared to other cestode representatives.

\section{Non-coding regions}

The two largest non-coding regions in C. vulturi are designated as NC1 and NC2 (Table 1; Fig. 1). NC1 is 135 bp in length and is located between $\operatorname{trn} Y$ and trnS2. NC2 is $108 \mathrm{bp}$ long and is positioned between nad5 and trnG. These two large non-coding regions were predicted each to form two stem-loop structures (Additional file 3: Figure $\mathrm{S} 2$ ). One stem-loop structure in $\mathrm{NC1}$ has ten nucleotide pairs and a loop of 3 nt while the other has 27 nucleotide pairs with a loop of 13 nt (Additional file 3: Figure S2a). In the case of $\mathrm{NC} 2$, one stem-loop structure has six nucleotide pairs and a loop of $5 \mathrm{nt}$ and the other has 31 nucleotide pairs with a loop of 13 nt (Additional file 3: Figure S2b). The longer secondary structure of $\mathrm{NC} 1$ includes a T-rich region (Additional file 3: Figure S2a). Palindromes and several copies of the dinucleotide AT were found in the two non-coding regions. These potential secondary structures and unique features of AT or $\mathrm{T}$ richness and palindromes are also found in the non-coding regions of representatives of three other cestode genera, i.e. Taenia, Echinococcus and Hymenolepis [33]. The function of these secondary structures in non-coding regions remains unknown. However, similar secondary structures have been shown to initiate replication and transcription in mammals [32], and it is possible that the secondary structures in the non-coding regions of tapeworms have a similar function.

\section{Phylogenetic analysis}

Bayesian inference and Maximum Likelihood methods were used to construct the phylogenetic trees; as these exhibited identical topology and support, only the topology resulting from the ML analysis is shown in Fig. 2. Representatives of the Pseudophyllidea (Diphyllobothriidae) and Cyclophyllidea (Anoplocephalidae, Dipylidiidae, Hymenolepididae, Paruterinidae and Taeniidae) formed strongly supported independent clades. The Taeniidae included four different clades and was resolved as an independent group within the order Cyclophyllidea (Fig. 2). The Hymenolepididae exhibited a sister-group relationship with the Anoplocephalidae, consistent with what has been reported in studies based on $18 \mathrm{~S}$ rDNA $[4,9]$ and $12 \mathrm{~S}$ rDNA [34]. This is also in accordance with cladistic analyses based on morphological characters by Hoberg et al. [3]. Representatives of the Taeniidae formed a strongly supported clade and C. vulturi appeared as the sister taxon with maximum support.

Gene rearrangement comparisons used as phylogenetic tools have been used to analyze several evolutionary relationships, the closest taxa sharing an identical gene order [16]. The mt genome of $C$. vulturi has a different gene order to those of species in the family Taeniidae. This result lends further support to the current classification, where the genus Cladotaenia is not a member of the family Taeniidae [1]. 
Table 2 Properties of protein-coding genes, length of the mt genomes and rRNA genes and AT content of cestode mt genomes

\begin{tabular}{|c|c|c|c|c|c|c|c|c|c|c|c|c|}
\hline \multirow[t]{2}{*}{ Gene } & \multicolumn{12}{|c|}{ Species } \\
\hline & T. S. & T. a. & E. $g$. & E. $m$. & H. k. & H. p. & V. $m$. & D. C. & A. $p$. & A. $m$. & H. d. & C. v. \\
\hline \multicolumn{13}{|c|}{ Number of aa } \\
\hline $\cos 3$ & 214 & 214 & 215 & 215 & 214 & 214 & 215 & 215 & 214 & 214 & 216 & 214 \\
\hline cytb & 355 & 355 & 355 & 355 & 355 & 354 & 355 & 360 & 366 & 366 & 365 & 364 \\
\hline nad4L & 86 & 86 & 86 & 86 & 86 & 86 & 86 & 86 & 86 & 86 & 86 & 86 \\
\hline nad4 & 403 & 417 & 419 & 404 & 416 & 416 & 419 & 415 & 415 & 415 & 409 & 414 \\
\hline atp6 & 171 & 171 & 170 & 171 & 172 & 171 & 171 & 171 & 171 & 171 & 171 & 171 \\
\hline nad2 & 293 & 293 & 293 & 293 & 295 & 294 & 291 & 290 & 291 & 291 & 293 & 291 \\
\hline nad1 & 297 & 297 & 297 & 297 & 297 & 298 & 297 & 297 & 296 & 296 & 296 & 296 \\
\hline nad3 & 115 & 115 & 115 & 115 & 113 & 113 & 115 & 114 & 115 & 115 & 115 & 115 \\
\hline $\cos 1$ & 539 & 539 & 557 & 535 & 543 & 538 & 539 & 580 & 530 & 529 & 517 & 527 \\
\hline $\cos 2$ & 193 & 191 & 193 & 193 & 194 & 194 & 192 & 191 & 191 & 191 & 192 & 193 \\
\hline nad6 & 150 & 150 & 151 & 151 & 150 & 149 & 152 & 151 & 152 & 152 & 152 & 151 \\
\hline nad5 & 522 & 522 & 523 & 524 & 522 & 524 & 522 & 521 & 526 & 526 & 524 & 522 \\
\hline \multicolumn{13}{|c|}{ Length of rRNA gene (bp) } \\
\hline $\mathrm{rrnL}$ & 980 & 975 & 967 & 983 & 960 & 961 & 963 & 970 & 981 & 973 & 967 & 964 \\
\hline rrns & 705 & 731 & 726 & 704 & 728 & 730 & 727 & 729 & 724 & 724 & 709 & 715 \\
\hline \multicolumn{13}{|c|}{ Deduced initiation codon } \\
\hline $\cos 3$ & ATG & ATG & ATG & ATG & ATG & ATG & ATG & ATG & ATG & ATG & ATG & GTG \\
\hline cytb & ATG & ATG & ATG & ATG & ATG & ATG & ATG & ATG & GTG & GTG & ATG & ATG \\
\hline nad4L & ATG & ATG & GTG & GTG & ATG & ATG & ATG & ATG & ATG & GTG & ATG & ATG \\
\hline nad4 & GTG & ATG & ATG & ATG & GTG & ATG & ATG & GTG & ATG & GTG & ATT & GTG \\
\hline atp6 & ATG & ATG & ATG & ATG & ATG & ATG & ATG & ATG & ATG & ATG & ATG & ATG \\
\hline nad2 & ATG & ATG & ATG & ATG & ATG & ATG & ATG & ATG & ATG & ATG & ATG & ATG \\
\hline nadl & ATG & ATG & GTG & ATG & GTG & ATG & ATG & ATG & ATG & GTG & ATG & ATG \\
\hline nad3 & ATG & ATG & ATG & ATG & ATG & ATG & ATG & ATG & ATG & ATG & ATG & GTG \\
\hline $\operatorname{cox} 1$ & ATG & ATG & ATG & ATG & ATG & ATG & ATG & ATG & ATG & ATG & $\pi T$ & GTG \\
\hline $\cos 2$ & ATG & ATG & GTG & GTG & ATG & ATG & ATG & ATG & ATG & ATG & ATG & GTG \\
\hline nad6 & ATG & GTG & ATG & ATG & GTG & ATG & ATG & ATG & ATG & ATG & ATG & ATG \\
\hline nad5 & ATG & ATG & ATG & ATG & ATG & ATG & ATG & ATG & ATG & ATG & ATG & ATG \\
\hline \multicolumn{13}{|c|}{ Deduced termination codon } \\
\hline $\cos 3$ & TAG & TAG & TAG & TAG & TAA & TAA & TAG & $\mathrm{T}$ & TA & TA & TAG & TAA \\
\hline cytb & TAA & TAA & TAA & TAA & TAA & TAA & TAA & TAG & TAG & TAA & TAG & TA \\
\hline nad4L & TAA & TAG & TAA & TAG & TAG & TAA & TAG & TAG & TAG & TAG & TAG & TAA \\
\hline nad4 & TAG & TAG & TAG & TAG & TAG & TAA & TAA & TAA & TAA & TAG & TAG & TAA \\
\hline atp6 & TAA & TAA & TAG & TAG & TAG & TAG & TAA & TAG & TAG & TAG & TAG & TAA \\
\hline nad2 & TAA & TAA & TAG & TAG & TAA & TAA & TAG & $\mathrm{T}$ & TAG & TAG & TAG & TAA \\
\hline nadl & $\mathrm{T}$ & $\mathrm{T}$ & TAA & TAG & TAG & TAG & TAG & TAA & TAA & TAA & TAG & TAA \\
\hline nad3 & TAG & TAG & TAG & TAA & $\mathrm{T}$ & TAG & TAG & TAG & TAA & TAA & TAG & TAG \\
\hline $\operatorname{cox} 1$ & TAG & TAA & TAA & TAG & TAA & TAG & TAG & TAA & TAA & TAG & $\mathrm{T}$ & TAG \\
\hline $\cos 2$ & TAG & TAG & TAG & TAG & $\mathrm{T}$ & $\mathrm{T}$ & TAG & TAG & TAG & TAG & TAA & TAA \\
\hline nad6 & TAG & TAA & TAG & TAA & TAG & TAA & TAA & TAG & TAG & TAG & TAA & TAG \\
\hline nad5 & TAA & TAA & TAA & TAA & TAG & TAA & TAA & TAA & TAG & TAA & TAG & TAA \\
\hline
\end{tabular}


Table 2 Properties of protein-coding genes, length of the mt genomes and rRNA genes and AT content of cestode mt genomes (Continued)

Length of $\mathrm{mt}$ genome (bp)

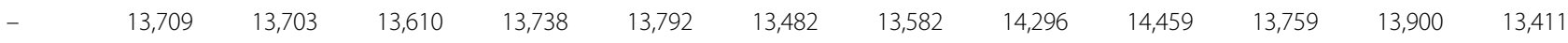

AT content of complete mt genome (\%)

\begin{tabular}{lllllllllllll}
- & 72.05 & 71.40 & 67.02 & 69.04 & 72.77 & 71.40 & 71.37 & 72.89 & 71.05 & 70.80 & 71.04 & 74.64 \\
\hline
\end{tabular}

Note: Results obtained from GenBank accessions

Abrreviations: T. s. Taenia solium, T. a. Taenia asiatica, E. g. Echinococcus granulosus, E. m. Echinococcus multilocularis, H. k. Hydatigera krepkogorski, H. p. Hydatigera parva, V. m. Versteria mustelae, D. c. Dipylidium caninum, A. p. Anoplocephala perfoliata, H. d. Hymenolepis diminuta, D. n. Diphyllobothrium nihonkaiense, D. I. Diphyllobothrium latum, D. g. Diplogonoporus grandis, D. b. Diplogonoporus balaenopterae, S. e. Spirometra erinaceieuropaei, C. v. Cladotaenia vulturi

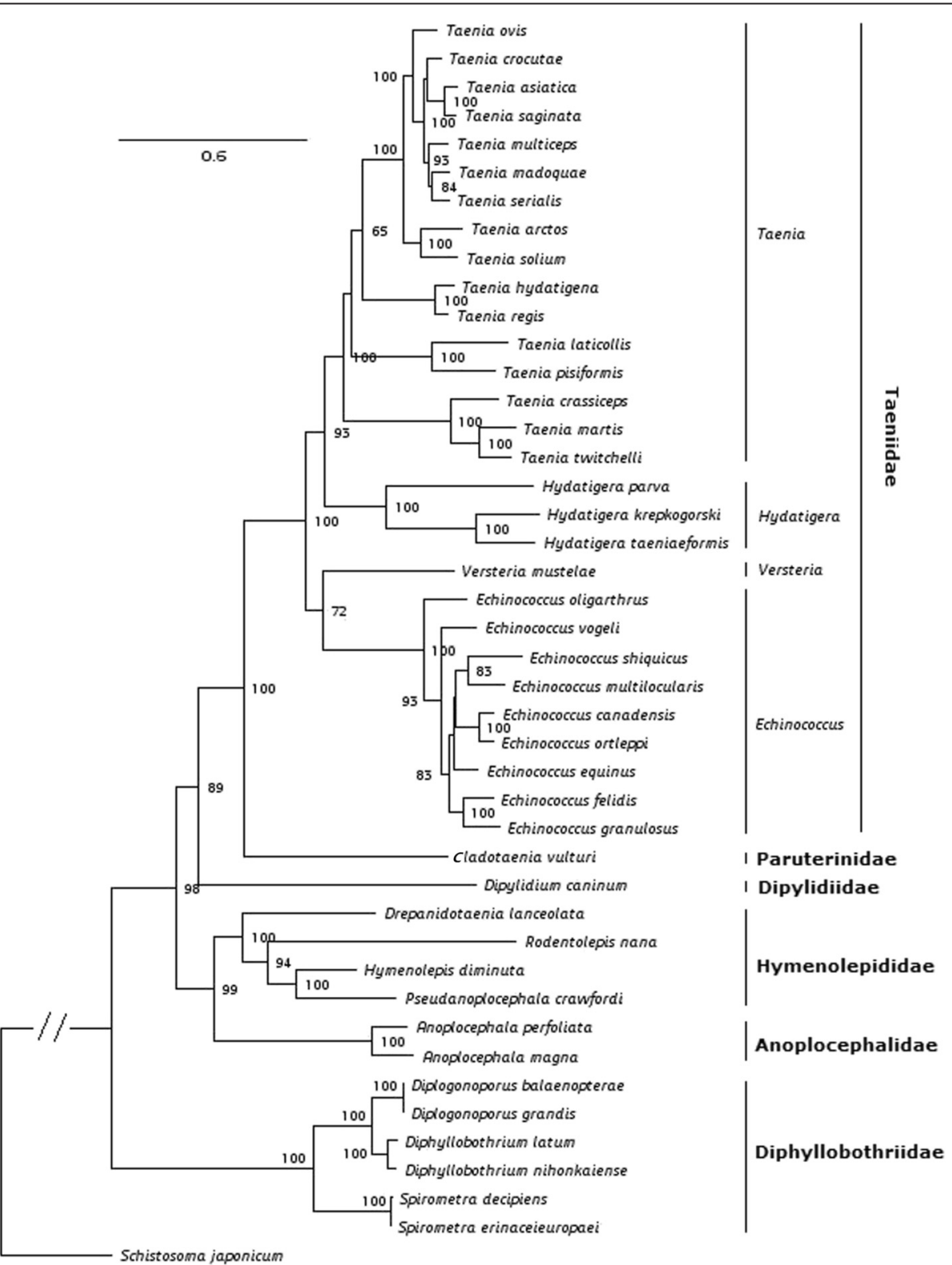

Fig. 2 Phylogenetic relationships among members of the Anoplocephalidae, Dipylidiidae, Hymenolepididae, Paruterinidae and Taeniidae. Tree from a Maximum Likelihood analysis using deduced amino acids of 12 protein-coding genes with bootstrapping frequency values shown at the nodes 
In the present phylogeny, four clades were formed by the genera Taenia, Hydatigera, Versteria and Echinococcus within the Taeniidae, coincident with previously published estimations of the relationships between the suprageneric taxa within the family and the Cyclophyllidea [10, 34]. Furthermore, the internal topologies of all of the clades within the Taeniidae are fully identical to those inferred from amino acids of the 12 protein-coding genes using Dipylidium caninum as the outgroup [10, 34]. Additionally, a sister-group relationship between Echinococcus spp. and $V$. mustelae was supported and identical to those inferred from both mt protein-coding genes and nuclear genes (pepck and pold) using Dipylidium caninum as the outgroup, but inconsistent to the phylogenies reconstructed using $18 \mathrm{~S}$ rDNA suggesting that $V$. mustelae is a sister taxon to Taenia spp. [10,34]. Additional evidence is required to fully understand the relationship between Versteria and Echinococcus. Furthermore, C. vulturi is closely related to the species in the family Taeniidae with strong support in the topology of the current analysis, further supporting the hypothesis of a sistergroup relationship between the Paruterinidae and Taeniidae based on an early morphological study by Hoberg et al. [3].

\section{Relative synonymous codon usage}

Analysis of the relative synonymous codon usage (RSCU) of the 12 protein-coding genes may shed light on the general codon usage patterns of evolution among the cestode species. Numbers of each amino acid and their RSCU values in the $\mathrm{mt}$ protein-coding genes of a range of the cestode species used to infer the phylogeny in Fig. 2 were calculated in this study (Additional file 4: Table S2). The result showed that the same codons tend to be most common in all species. That means the common pattern of bias is observed. The most common codons are UUA, ACU, GCU, UGA in every case, while UAA, UAG, CGC are the least common codons. The cluster analysis based on the divergence in codon usage (Additional file 5: Figure S3) showed that four groups were classified by RSCU with members of the Taeniidae dispersed in different clusters with taxonomic content different from the phylogenetic hypothesis based on the 12 protein-coding gene sequences. The distance tree inferred from the values of RSCU failed to recover the topology expected from the known systematic relationships among cestode species. This result supports the opinion that base composition differences may affect tree topologies [35, 36].

The mt genome of C. vulturi described here provides data for the first member of the family Paruterinidae sequenced. Additional molecular data with more taxa from a wide range of lineages, including Cladotaenia spp. and other species in the Paruterinidae, is required to assess the phylogenetic position of the family Paruterinidae within the order Cyclophyllidea.

\section{Conclusions}

In the current study, the complete mt genome of $C$. vulturi was sequenced and characterized. It contains 36 genes, including 22 transfer RNA genes, two ribosomal RNA genes and 12 protein-coding genes. Phylogenetic analyses inferred from amino acid sequences of the 12 protein-coding genes suggest that $C$. vulturi is a sister taxon to the species of the family Taeniidae. The novel $\mathrm{mt}$ genome sequence provided here will be useful in further investigations of the comparative mitochondrial genomics and systematics of parasitic tapeworms.

\section{Additional files}

Additional file 1: Table S1. Primers used for amplifying mtDNA fragments and their positions in the mt genome of Cladotaenia vulturi. (DOC $30 \mathrm{~kb}$ )

Additional file 2: Figure S1. Deduced secondary structures for the four tRNA genes of Cladotaenia vulturi mt genome. Only these four tRNA genes lack typical cloverleaf structure. (DOC 168 kb)

Additional file 3: Figure S2. Putative secondary structures of the two non-coding regions in Cladotaenia vulturi mt genome. a The long non-coding region (NC1) located between $\operatorname{trn} \mathrm{C}$ and $\operatorname{trn} \mathrm{S2}$. $\mathbf{b}$ The short non-coding region (NC2) between nad5 and trnG. (DOC $102 \mathrm{~kb}$ )

Additional file 4: Table S2. Codon frequencies $(\mathrm{N})$ and relative synonymous codon usage (RSCU) values in $12 \mathrm{mt}$ protein-coding genes of cestode species. (DOC $1068 \mathrm{~kb}$ )

Additional file 5: Figure S3. Distance tree based on the RSCU values for $12 \mathrm{mt}$ protein-coding genes of cestode species used in the phylogenetic analyses. (DOC $147 \mathrm{~kb}$ )

\section{Acknowledgements \\ The author wishes to thank Shiwei Wang and Jun Shi for providing samples for this study. The author would like to express appreciation to Dr Shuai Wang for providing language help and constructive suggestions in this manuscript. Project support was provided by the International Science \& Technology Cooperation Program of China (Grant No. 2013DFA31840).}

Funding

Not applicable.

\section{Availability of data and material}

The datasets supporting the conclusions of this article are available in the GenBank database (accession nos. KU559932, KP241938).

\section{Competing interests}

The author declares that she has no competing interests.

Consent for publication

Not applicable.

Ethics approval and consent to participate Not applicable.

Received: 18 April 2016 Accepted: 22 August 2016

Published online: 31 August 2016

\section{References}

1. Khalil LF, Jones A, Bray RA. Keys to the cestode parasites of vertebrates. 1st ed. Wallingford: CAB International; 1994. 
2. Foronda P, Casanova JC, Valladares B, Martinez E, Feliu C. Molecular systematics of several cyclophyllid families (Cestoda) based on the analysis of 18S ribosomal DNA gene sequences. Parasitol Res. 2004;93(4):279-82.

3. Hoberg EP, Jones A, Bray RA. Phylogenetic analysis among the families of the Cyclophyllidea (Eucestoda) based on comparative morphology, with new hypotheses for co-evolution in vertebrates. Syst Parasitol. 1999:42(1):51-73.

4. Mariaux J. A molecular phylogeny of the Eucestoda. J Parasitol. 1998;84(1):114-24.

5. Olson PD, Tkach W. Advances and trends in the molecular systematics of the parasitic Platyhelminthes. Adv Parasitol. 2005;60:165-243.

6. Olson PD, Littlewood DT, Bray RA, Mariaux J. Interrelationships and evolution of the tapeworms (Platyhelminthes: Cestoda). Mol Phylogenet Evol. 2001;19(3):443-67.

7. Haukisalmi V, Hardman LM, Hardman M, Laakkonen J, Niemimaa J, Henttonen H. Morphological and molecular characterisation of Paranoplocephala buryatiensis n. sp. and P. Iongivaginata Chechulin \& Gulyaev, 1998 (Cestoda: Anoplocephalidae) in voles of the genus Clethrionomys. Syst Parasitol. 2007;66(1):55-71.

8. Lee SU, Chun HC, Huh S. Molecular phylogeny of parasitic Platyhelminthes based on sequences of partial 28S rDNA D1 and mitochondrial cytochrome c oxidase subunit I. Korean J Parasitol. 2007;45(3):181-9.

9. Taleb-Hossenkhan N, Bhagwant S. Molecular characterization of the parasitic tapeworm Bertiella studeri from the island of Mauritius. Parasitol Res. 2012;110(2):759-68.

10. Nakao M, Lavikainen A, Iwaki T, Haukisalmi V, Konyaev S, Oku Y, et al. Molecular phylogeny of the genus Taenia (Cestoda: Taeniidae): proposals for the resurrection of Hydatigera Lamarck, 1816 and the creation of a new genus Versteria. Int J Parasitol. 2013;43(6):427-37.

11. Rokas A, Holland PW. Rare genomic changes as a tool for phylogenetics. Trends Ecol Evol. 2000;15(11):454-9.

12. Littlewood DT, Lockyer AE, Webster BL, Johnston DA, Le TH. The complete mitochondrial genomes of Schistosoma haematobium and Schistosoma spindale and the evolutionary history of mitochondrial genome changes among parasitic flatworms. Mol Phylogenet Evol. 2006;39(2):452-67.

13. Boore JL, Lavrov DV, Brown WM. Gene translocation links insects and crustaceans. Nature. 1998;392(6677):667-8.

14. Humphreys-Pereira DA, Elling AA. Mitochondrial genomes of Meloidogyne chitwoodi and M. incognita (Nematoda: Tylenchina): comparative analysis, gene order and phylogenetic relationships with other nematodes. Mol Biochem Parasitol. 2014;194(1-2):20-32.

15. Boore JL, Brown WM. Big trees from little genomes: mitochondrial gene order as a phylogenetic tool. Curr Opin Genet Dev. 1998;8(6):668-74.

16. Smith MJ, Arndt A, Gorski S, Fajber E. The phylogeny of echinoderm classes based on mitochondrial gene arrangements. J Mol Evol. 1993;36(6):545-54

17. Boore $J$, Collins TM, Stanton D, Daehler LL, Brown WM. Deducing the pattern of arthropod phylogeny from mitochondrial DNA rearrangements. Nature. 1995;376(6536):163-5.

18. Dowton M. Relationships among the cyclostome braconid (Hymenoptera: Braconidae) subfamilies inferred from a mitochondrial tRNA gene rearrangement. Mol Phylogenet Evol. 1999;11(2):283-7.

19. Kurabayashi A, Ueshima R. Complete sequence of the mitochondrial DNA of the primitive opisthobranch gastropod Pupa strigosa: systematic implication of the genome organization. Mol Biol Evol. 2000;17(2):266-77.

20. Boore JL, Brown WM. Mitochondrial genomes of Galathealinum, Helobdella, and Platynereis: sequence and gene arrangement comparisons indicate that Pogonophora is not a phylum and Annelida and Arthropoda are not sister taxa. Mol Biol Evol. 2000;17(1):87-106.

21. Guo A. The complete mitochondrial genome of Anoplocephala perfoliata, the first representative for the family Anoplocephalidae. Parasit Vectors. 2015;8:549.

22. Guo A. Complete mitochondrial genome of Anoplocephala magna solidifying the species. Korean J Parasitol. 2016;54(3):369-73.

23. Zuker M. Mfold web server for nucleic acid folding and hybridization prediction. Nucleic Acids Res. 2003;31(13):3406-15.

24. Katoh K, Standley DM. MAFFT multiple sequence alignment software version 7: improvements in performance and usability. Mol Biol Evol. 2013;30(4):772-80.

25. Talavera G, Castresana J. Improvement of phylogenies after removing divergent and ambiguously aligned blocks from protein sequence alignments. Syst Biol. 2007;56(4):564-77.

26. Darriba D, Taboada GL, Doallo R, Posada D. ProtTest 3: fast selection of best-fit models of protein evolution. Bioinformatics. 2011;27(8):1164-5.
27. Guindon S, Gascuel O. A simple, fast, and accurate algorithm to estimate large phylogenies by maximum likelihood. Syst Biol. 2003;52(5):696-704.

28. Ronquist F, Teslenko M, van der Mark P, Ayres DL, Darling A, Hohna S, et al. MrBayes 3.2: efficient Bayesian phylogenetic inference and model choice across a large model space. Syst Biol. 2012;61(3):539-42.

29. Rota-Stabelli O, Yang Z, Telford MJ. MtZoa: a general mitochondrial amino acid substitutions model for animal evolutionary studies. Mol Phylogenet Evol. 2009;52(1):268-72.

30. Sharp PM, Li WH. An evolutionary perspective on synonymous codon usage in unicellular organisms. J Mol Evol. 1986;24(1-2):28-38.

31. Le TH, Pearson MS, Blair D, Dai N, Zhang LH, McManus DP. Complete mitochondrial genomes confirm the distinctiveness of the horse-dog and sheep-dog strains of Echinococcus granulosus. Parasitology. 2002;124(Pt1):97-112.

32. Wolstenholme DR. Animal mitochondrial DNA: structure and evolution. Int Rev Cytol. 1992:141:173-216.

33. von Nickisch-Rosenegk M, Brown WM, Boore JL. Complete sequence of the mitochondrial genome of the tapeworm Hymenolepis diminuta: gene arrangements indicate that Platyhelminths are Eutrochozoans. Mol Biol Evol. 2001;18(5):721-30.

34. von Nickisch-Rosenegk M, Lucius R, Loos-Frank B. Contributions to the phylogeny of the Cyclophyllidea (Cestoda) inferred from mitochondrial $12 \mathrm{~S}$ rDNA. J Mol Evol. 1999:48(5):586-96.

35. Le TH, McManus DP, Blair D. Codon usage and bias in mitochondrial genomes of parasitic platyhelminthes. Korean J Parasitol. 2004;42(4):159-67.

36. Foster PG, Hickey DA. Compositional bias may affect both DNA-based and protein-based phylogenetic reconstructions. J Mol Evol. 1999;48(3):284-90.

\section{Submit your next manuscript to BioMed Central and we will help you at every step:}

- We accept pre-submission inquiries

- Our selector tool helps you to find the most relevant journal

- We provide round the clock customer support

- Convenient online submission

- Thorough peer review

- Inclusion in PubMed and all major indexing services

- Maximum visibility for your research

Submit your manuscript at www.biomedcentral.com/submit
Ciomed Central 